\title{
Molecular diversity of HIV-1 in Croatia
}

\author{
Ivana Grgic ${ }^{*}$, Ana Planinic ${ }^{1}$, Lana Gorenec ${ }^{1}$, Adriana Vince², Josip Begovac², Snjezana Zidovec Lepej ${ }^{1}$ \\ From The 7th Romanian National HIV/AIDS Congress and The 2nd Central European HIV Forum \\ Sibiu, Romania. 29-31 May 2014
}

Croatia is a small southeastern European country with a low prevalence of HIV infection and a centralized system of clinical care. The cumulative number of HIV infections in the period 1985-2013 was 1,102. The aim of this study was to analyze the distribution of HIV-1 subtypes in Croatia.

The study enrolled 356 HIV-infected patients $(86.2 \%$ males) receiving clinical care at the Croatian Reference Center for HIV/AIDS in the period 2000-2013. The patients were classified into three groups based on the year of genotyping and entrance to clinical care (20002005, 2006-2010 and 2011-2013). Population-based sequencing of the part of pol gene was performed by using TRUGENE ${ }^{\circledR}$ HIV-1 Genotyping System. HIV-1 subtypes were determined by HIV REGA Subtyping Tool.

Subtype B was detected in 279 of 356 patients (78.37\%). In the period 2000-2005, a total of $28.3 \%$ (47/166) of patients were infected with non-B subtypes. More recently, percentages of non-B subtypes decreased to $14.9 \%$ (20/134 patients, 2006-2010) and 17.8\% (10 of 56 patients, 2011-2013). Non-B subtypes were detected in 27 of 49 (55.1\%) HIV-infected women. A total of 93.1\% $(175 / 188)$ men who have sex with men (MSM) patients were infected with subtype $B$.

The majority of HIV-1 infections in Croatia can be attributed to subtype B, particularly among MSM. Non-B subtypes are associated mainly with heterosexual transmission.

\footnotetext{
Authors' details

${ }^{1}$ Department of Molecular Diagnostics and Flow Cytometry, University Hospital for Infectious Diseases "Dr. Fran Mihaljevic", Zagreb, Croatia.

¿University of Zagreb, School of Medicine, Zagreb, Croatia.
}

Published: 29 May 2014

'Department of Molecular Diagnostics and Flow Cytometry, University Hospital for Infectious Diseases "Dr. Fran Mihaljevic", Zagreb, Croatia Full list of author information is available at the end of the article
doi:10.1186/1471-2334-14-S4-05

Cite this article as: Grgic et al: Molecular diversity of HIV-1 in Croatia.

BMC Infectious Diseases 2014 14(Suppl 4):O5.
Submit your next manuscript to BioMed Central and take full advantage of:

- Convenient online submission

- Thorough peer review

- No space constraints or color figure charges

- Immediate publication on acceptance

- Inclusion in PubMed, CAS, Scopus and Google Scholar

- Research which is freely available for redistribution
() Biomed Central

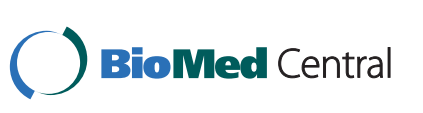

(c) 2014 Grgic et al; licensee BioMed Central Ltd. This is an Open Access article distributed under the terms of the Creative Commons Attribution License (http://creativecommons.org/licenses/by/4.0), which permits unrestricted use, distribution, and reproduction in any medium, provided the original work is properly cited. The Creative Commons Public Domain Dedication waiver (http:// creativecommons.org/publicdomain/zero/1.0/) applies to the data made available in this article, unless otherwise stated. 